\title{
A Rapid Technique for Prediction of Nutrient Release from Polymer Coated Controlled Release Fertilizers
}

\author{
Shengsen Wang ${ }^{1}$, Ashok K. Alva ${ }^{*}$, Yuncong $\mathrm{Li}^{2}$, Min Zhang ${ }^{3}$ \\ ${ }^{1}$ USDA-ARS, 24106 N. Bunn Road, Prosser, WA99350; ${ }^{2}$ University of Florida, Tropical Research and Education Center, Homestead, \\ USA; ${ }^{3}$ Shandong Agricultural University, College of Resources and Environment, Taian, China. \\ Email: "ashok.alva@ars.usda.gov
}

Received July $28^{\text {th }}, 2011$; revised August $15^{\text {th }}, 2011$; accepted August $21^{\text {st }}, 2011$

\begin{abstract}
Controlled release fertilizers (CRF) are produced with different rates and durations of nutrient release to cater to different crops with wide ranges of nutrient requirements. A rapid technique is needed to verify the label specifications of nutrient release rate and duration. Polymer-coated urea $(P C U)(43 \%$ nitrogen $[N])$ and polymer-coated $N$, phosphorus $(P)$, potassium $(K)$ (PC_NPK; 14-14-14) fertilizer products were used in this study. Soil incubation of the above CRF products at $25^{\circ} \mathrm{C}$ showed that $63.6 \%$ to $70.8 \%$ of total $N$ was released over 220 days (d). At $100^{\circ} \mathrm{C}$ in water $100 \%$ of $N$ release occurred in about 168 to 216 hours ( $h$ ). Regression equations were developed for cumulative nutrient release as a function of release time separately at $25^{\circ} \mathrm{C}$ and $100^{\circ} \mathrm{C}$. Using the above regressions, the release duration for a given percent nutrient release at each temperature was calculated. These values were then used to establish a relationship between the release duration at $25^{\circ} \mathrm{C}$ as a function of that at $100^{\circ} \mathrm{C}$. This relationship is useful to predict the release duration at $25^{\circ} \mathrm{C}$ of an unknown CRF product by conducting a rapid release test in water at $100^{\circ} \mathrm{C}$. This study demonstrated that a rapid nutrient release test at $100^{\circ} \mathrm{C}$ successfully predicted nutrient release rate and duration at $25^{\circ} \mathrm{C}$, for polymer coated fertilizers. Therefore, this rapid test can be used to verify the label release rate and duration of most CRF products.
\end{abstract}

Keywords: Nutrient Requirement, Nutrient Management, polymer Coated Fertilizer, Slow Release Fertilizer

\section{Introduction}

Potential benefit of controlled release fertilizers (CRF) is the ability to manipulate the rate and duration of nutrient release, so that the product can be applied once a year to supply the nutrient requirement over the entire annual growing period $[1,2]$. The duration of nutrient release can vary for several months depending on the coating specification and duration of crop growth. Although coating can be applied on any nutrient granules, much of the interest and justification for coating is on nitrogen $(\mathrm{N})$ source. This is due to the complexity of $\mathrm{N}$ transformations in the soil that ultimately produces nitrate $\left(\mathrm{NO}_{3}-\mathrm{N}\right)$ form, which is highly vulnerable to leaching down the soil profile if not taken up by the plant roots. Under conditions that favour downward transport of water below the root zone, the $\mathrm{NO}_{3}-\mathrm{N}$ can be carried by leaching water deeper into the vadose zone and can contaminate surficial aquifer. Hence, there is a need to develop tech- niques to mitigate $\mathrm{NO}_{3}-\mathrm{N}$ leaching below the rootzone. Most of the studies on nutrient release by the CRF products are based on the $\mathrm{N}$ release $[3,4]$. In a coated $\mathrm{N}$, phosphorus $(\mathrm{P})$, potassium $(\mathrm{K})$ fertilizer the release of $\mathrm{N}$ was faster than that of $\mathrm{P}$ and $\mathrm{K}$ [4].

Verification of nutrient release pattern of CRF is critical for evaluation of effectiveness of these fertilizers for supplying plant nutrients according to the crop needs and the duration of crop growth. Despite a variety of prediction models and methods to evaluate the nutrient release [5-10] being developed in the past, there is no consistent and standardized method being recognized to date [1012]. However, these predictions were relying heavily on the characteristics of the coating materials. Nutrient release of polymer-coated CRF is primarily temperature dependent [4,13-16]. However, verification of nutrient release pattern and total duration at the ambient soil temperature is not feasible due to the prolonged duration of 
release expected for most CRF, i.e., 3 to 6 months. Medina et al. [17] used a laboratory procedure to predict $\mathrm{N}$ release rate of several slow release fertilizers. The method include extractions in $0.2 \%$ citric acid solution at 4 temperatures; i.e. $2 \mathrm{~h}$ at $25^{\circ} \mathrm{C}, 2 \mathrm{~h}$ at $40^{\circ} \mathrm{C}$, and $20 \mathrm{~h}$ at $50^{\circ} \mathrm{C}$, and $50 \mathrm{~h}$ at $60^{\circ} \mathrm{C}$. They reported that the above accelerated laboratory extraction procedure was successful in predicting $\mathrm{N}$ release rate of some slow release fertilizers. However, this method was not satisfactory for some other type of slow release fertilizers. Hence the need for a rapid nutrient release evaluation for verification of the product label nutrient release duration. An alternate approach is desirable to establish correlation between the nutrient release at high temperature (in a few d) vs. that at prevailing soil temperature during the growing season (several $\mathrm{d}$ to months). This correlation can be used to predict the rate and duration of nutrient release at ambient soil temperature by using the nutrient release measurement over a short duration at high temperature.

Dai and Fan [18] and Dai et al., [19,20], evaluated the nutrient release from two resin-coated $\mathrm{N}, \mathrm{P}, \mathrm{K}$ fertilizers (Trincote 1 and 2) at $25^{\circ} \mathrm{C}, 50^{\circ} \mathrm{C}, 60^{\circ} \mathrm{C}, 70^{\circ} \mathrm{C}, 80^{\circ} \mathrm{C}$ and $90^{\circ} \mathrm{C}$. They used the calibration of nutrient release at $80^{\circ} \mathrm{C}$ and $25^{\circ} \mathrm{C}$ as a model to predict the nutrient release rate at $25^{\circ} \mathrm{C}$ (in d) using the release results at $80^{\circ} \mathrm{C}$ (in h). The objective of this study was to develop and validate a rapid test for prediction of nutrient release at $25^{\circ} \mathrm{C}$ from polymer coated CRF products by using the measured nutrient release rate at $100^{\circ} \mathrm{C}$ temperature.

\section{Materials and Methods}

Two CRF products used in this study included: polymercoated urea (PCU); $43 \% \mathrm{~N}$ and polymer-coated $\mathrm{N}, \mathrm{P}, \mathrm{K}$ (14-14-14) (PC_NPK) fertilizers. Nitrogen release from these products was determined in water over $220 \mathrm{~d}$ at $25^{\circ} \mathrm{C}$, and $220 \mathrm{~h}$ at $100^{\circ} \mathrm{C}$.

\subsection{Nutrient Release at $100^{\circ} \mathrm{C}$}

A constant temperature extractor (Model HKQT, assembled at Shandong Agricultural University, Taian, China) was used to determine the nutrient release characteristics from the above two CRF products in deionized water at $100^{\circ} \mathrm{C}$. The extractor consisted of air-tight incubation chambers $(500 \mathrm{ml})$, stainless steelwire mesh containers, water bath, and temperature and pressure regulators. Ten grams of each CRF was placed in one of six wire mesh containers which submerged into $250 \mathrm{ml}$ deionized water in incubation chamber in three replications. The incubation chamber was preheated to $100^{\circ} \mathrm{C}$ at $100 \mathrm{kPa}$. The extractions $(50 \mathrm{ml})$ were collected at various time intervals from 1 to $220 \mathrm{~h}$ following incubation for analysis of total $\mathrm{N}$ in the extract using a total $\mathrm{N}$ analyzer (LiquiTOCII, Elementar Americas, Inc., Mt. Laurel, NJ). At each sampling, the remaining extract was depleted and another $250 \mathrm{ml}$ deionized water was added for the subsequent extraction.

\subsection{Incubation at $25^{\circ} \mathrm{C}$}

Nutrient release characteristics from CRF products in free water at $25^{\circ} \mathrm{C}$ was evaluated by following the procedure described by Dai et al. (2006). Ten grams of CRF product was weighed, sealed in nylon mesh bags, placed into plastic bottles containing $250 \mathrm{ml}$ deionized water, and bottles were incubated at $25^{\circ} \mathrm{C}$. Each treatment was replicated three times. Nutrient release at various sampling time, over $220 \mathrm{~d}$, was measured by sacrificing three bottles per treatment at each sampling time. Total $\mathrm{N}$ in an aliquot of the total extract was measured, as described above, and total $\mathrm{N}$ released from ten grams of the product at each sampling time was calculated.

\subsection{Model Development}

Total duration for over $90 \%$ release of nutrients at $100^{\circ} \mathrm{C}$ is in the range of several $\mathrm{h}$ or few $\mathrm{d}$ as compared to several $\mathrm{d}$ or months for similar magnitude of nutrient release at $25^{\circ} \mathrm{C}$. Therefore, a calibration between the nutrient release rates at $100^{\circ} \mathrm{C}$ and $25^{\circ} \mathrm{C}$ can be used to predict the nutrient release rate at $25^{\circ} \mathrm{C}$ by measuring the release rate at $100^{\circ} \mathrm{C}$. This can be accomplished by the following steps:

Determine nutrient release rates in water for a given CRF product at $100^{\circ} \mathrm{C}$ and $25^{\circ} \mathrm{C}$, until at least $80 \%$ to $90 \%$ of total nutrients are released at the respective temperatures.

Develop relationship between the cumulative nutrient release as percent of total nutrients in the product $(\mathrm{Y})$ and time $(\mathrm{X})$ at each temperature:

$$
\mathrm{Y}_{1}=\mathrm{A}_{1}+\mathrm{B}_{1} \mathrm{X}_{1}+\mathrm{C}_{1} \mathrm{X}_{1}^{2}
$$

where $Y_{1}=$ cumulative release at $100^{\circ} \mathrm{C} ; \mathrm{X}_{1}=$ release time (in $\mathrm{h}$ ); $\mathrm{A}_{1}, \mathrm{~B}_{1}$, and $\mathrm{C}_{1}$ are constants

$$
\mathrm{Y}_{2}=\mathrm{A}_{2}+\mathrm{B}_{2} \mathrm{X}_{2}+\mathrm{C}_{2} \mathrm{X}_{2}^{2}
$$

where $\mathrm{Y}_{2}=$ cumulative release at $25^{\circ} \mathrm{C} ; \mathrm{X}_{2}=$ release time (in d); $\mathrm{A}_{2}, \mathrm{~B}_{2}$, and $\mathrm{C}_{2}$ are constants.

From the above equations, we can calculate the time required for release of different percentages $\left(\mathrm{P}_{1}, \mathrm{P}_{2}, \mathrm{P}_{3}\right.$, $P_{4}$ and $P_{5}$ etc.) of total nutrients as $Z_{21}, Z_{22}, Z_{23}, Z_{24}$ and $Z_{25}$ etc. (in d) at $25^{\circ} \mathrm{C}$; and $Z_{11}, Z_{12}, Z_{13}, Z_{14}$, and $Z_{15}$ etc. (in h) at $100^{\circ} \mathrm{C}$. Notice that the percent of total nutrient released is similar for a given pair of release times at two different temperatures, i.e., $\mathrm{Z}_{21}$ and $\mathrm{Z}_{11}, \mathrm{Z}_{22}$ and $\mathrm{Z}_{12}$ and so on.

Using the above paired values, we can then establish relationship between the nutrient release time at $25^{\circ} \mathrm{C}$ as a function of that at $100^{\circ} \mathrm{C}$ as follows: 


$$
\mathrm{Z}_{2}=\mathrm{P}+\mathrm{MZ}_{1}+\mathrm{NZ}_{1}^{2}
$$

where $Z_{2}=$ release time (in d) at $25^{\circ} \mathrm{C} ; \mathrm{Z}_{1}=$ release time (in h) at $100^{\circ} \mathrm{C}$;

$\mathrm{P}, \mathrm{M}$, and $\mathrm{N}$ are constants.

Therefore, once we know the release time at $100^{\circ} \mathrm{C}$ for a given percent release of nutrients from an unknown CRF product, we can use equation \#3 to calculate the release time at $25^{\circ} \mathrm{C}$ for the same percent release.

\section{Results and Discussion}

\subsection{Release Characteristics of Two CRF Products at $25^{\circ} \mathrm{C}$ and $100^{\circ} \mathrm{C}$}

At $100^{\circ} \mathrm{C}$ (Figure 1), $100 \%$ of total $\mathrm{N}$ in PCU and PC NPK was released in about 220 hours. In contrast, at $25^{\circ} \mathrm{C}$ only $63.6 \%$ to $70.8 \%$ of total $\mathrm{N}$ from the above two products were released over a period of $220 \mathrm{~d}$. At $100^{\circ} \mathrm{C}$, percent $\mathrm{N}$ release from $\mathrm{PCU}$ was generally greater than that from PC_NPK at any given time throughout the incubation, except the initial $7 \mathrm{~h}$. At $25^{\circ} \mathrm{C}$, percent $\mathrm{N}$ release was greater from PCU than that from PC_NPK during first $100 \mathrm{~d}$. Subsequently, however, the trend was reversed until the end of $216 \mathrm{~d}$ incubation period. The percent release of $\mathrm{N}$ increased at a rapid rate during the first $56 \mathrm{~d}$ at $25^{\circ} \mathrm{C}$, followed by a slow rate during the rest of incubation.

\subsection{Predicting Total $\mathrm{N}$ release at $25^{\circ} \mathrm{C}$ by Using Measured Release at $100^{\circ} \mathrm{C}$}

The relationship between cumulative percent release of $\mathrm{N}$ and release time is described by quadratic or cubic functions both at $25^{\circ} \mathrm{C}$ and $100^{\circ} \mathrm{C}$ for both products (Table 1). The regression equations are highly significant with $\mathrm{R}^{2}>$ 0.98 . Using these regressions, the times required for a different percent release of total $\mathrm{N}$ were calculated at both $25^{\circ} \mathrm{C}$ and $100^{\circ} \mathrm{C}$ (Table 2). The $Z_{1}$ and $Z_{2}$ values for each $\mathrm{CRF}$ product were then used to establish regressions between release time at $25^{\circ} \mathrm{C}$ as a function of that at $100^{\circ} \mathrm{C}$ for each product (Table 1). These regressions were also highly significant with $\mathrm{R}^{2}>0.998$.

\subsection{Application of the above Model to Predict Total N Release at $25^{\circ} \mathrm{C}$}

If we have an unknown coated product of somewhat similar coating characteristics, a fast release test can be conducted at $100^{\circ} \mathrm{C}$. The release time for a given percent of total $\mathrm{N}$ at $100^{\circ} \mathrm{C}$ can then be used in either equation in Table 1 (depending on PCU or PC_NPK) to predict the time required to release the similar percent of total $\mathrm{N}$ in soil at $25^{\circ} \mathrm{C}$. Thus, the nutrient release pattern at $25^{\circ} \mathrm{C}$ can be predicted by using a fast nutrient release test at $100^{\circ} \mathrm{C}$ within h or a few $\mathrm{d}$.
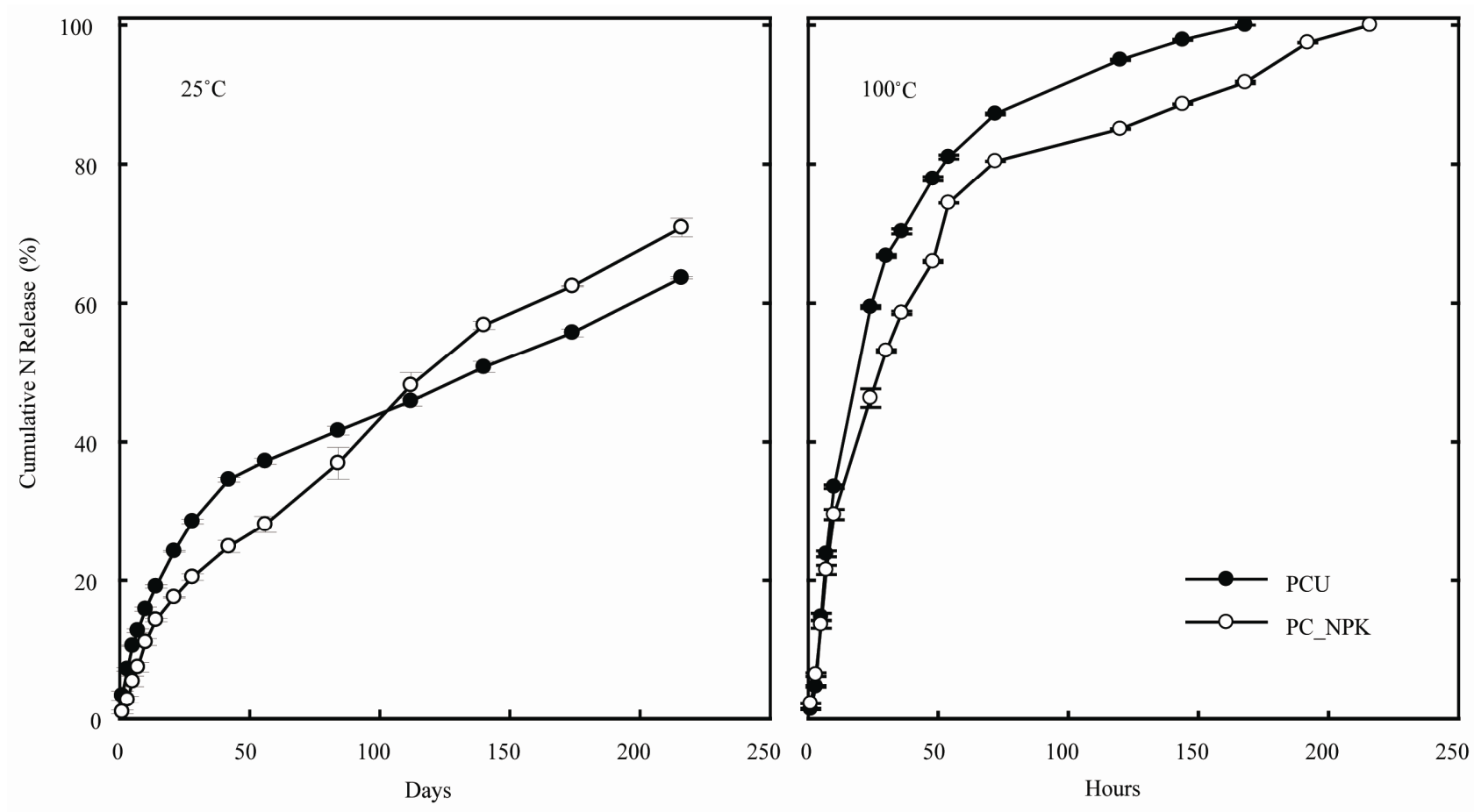

Release time

Figure 1. Cumulative release of nitrogen $(\mathrm{N})$ as percent of total $\mathrm{N}$ from polymer-coated urea (PCU) and Polymer-coated N, phosphorus (P), potassium (K) product (PC_NPK) in water at $25^{\circ} \mathrm{C}$ and $100^{\circ} \mathrm{C}$. 
Table 1. Relationship between cumulative percent release of total nitrogen $\left(Y_{1}\right.$ and $\left.Y_{2}\right)$ and time (in days $\left(X_{2}\right)$ for $25^{\circ} \mathrm{C}$ and in hours $\left(\mathrm{X}_{1}\right)$ for $100^{\circ} \mathrm{C}$ ), and equation for calculation of nutrient release at $25^{\circ} \mathrm{C}$ using the release time at $100^{\circ} \mathrm{C}$ for any given percent release.

Fertilizer Temp. Cumulative percent release of total $\mathrm{N}$ vs. time $\quad \mathrm{R}^{2} \quad$ Release time at $25^{\circ} \mathrm{C}$ as a function of that at $100^{\circ} \mathrm{C} \quad \mathrm{R}^{2}$

$$
25^{\circ} \mathrm{C} \quad \mathrm{Y}_{2}=6.381+0.874 \mathrm{X}_{2}-0.006 \mathrm{X}_{2}^{2}+0.00002 \mathrm{X}_{2}^{3} \quad 0.988 \quad \mathrm{Z}_{2}=-12.897+3.431 \mathrm{Z}_{1}+0.198 \mathrm{Z}_{1}^{2} \quad 0.998
$$

PCU

$100^{\circ} \mathrm{C} \quad \mathrm{Y}_{1}=3.446+2.618 \mathrm{X}_{1}-0.025 \mathrm{X}_{1}^{2}+0.00007 \mathrm{X}_{1}^{3} \quad 0.984$

$25^{\circ} \mathrm{C} \quad \mathrm{Y}_{2}=4.408+0.492 \mathrm{X}_{2}-0.001 \mathrm{X}_{2}^{2} \quad 0.990 \quad \mathrm{Z}_{2}=-45.908+14.424 \mathrm{Z}_{1}-0.510 \mathrm{Z}_{1}^{2}+0.007 \mathrm{Z}_{1}^{3} \quad 0.998$

PC NPK

$100^{\circ} \mathrm{C} \quad \mathrm{Y}_{1}=5.471+1.920 \mathrm{X}_{1}-0.014 \mathrm{X}_{1}^{2}+0.00003 \mathrm{X}_{1}^{3} \quad 0.989$

PCU = Polymer-Coated Urea; PC_NPK = Polymer Coated N, P, K fertilizer; All regressions are significant at P $\leq 0.001$.

Table 2. Calculated time (from Equations 1 and 2) for different cumulative release of $\mathrm{N}$ (as percent of total $\mathrm{N}$ ) for two controlled release fertilizers.

\begin{tabular}{ccccc}
\hline \multirow{2}{*}{$\begin{array}{c}\text { Cumulative re- } \\
\text { lease of N (per- }\end{array}$} & \multicolumn{3}{c}{ Time required for respective release } \\
\cline { 2 - 5 } cent of total N) & \multicolumn{2}{c}{ PCU } & \multicolumn{2}{c}{ PC_NPK } \\
\cline { 2 - 5 } & $100^{\circ} \mathrm{C}$ & $25^{\circ} \mathrm{C}$ & $100^{\circ} \mathrm{C}$ & $25^{\circ} \mathrm{C}$ \\
\hline 10 & $\mathrm{~h}$ & $\mathrm{~d}$ & $\mathrm{~h}$ & $\mathrm{~d}$ \\
20 & 3.4 & 4.5 & 4.4 & 9.6 \\
30 & 6.7 & 14.5 & 6.9 & 27.6 \\
40 & 9.0 & 31.2 & 11.1 & 64.9 \\
50 & 13.4 & 73.6 & 19.3 & 92.1 \\
60 & 20.1 & 136.1 & 27.7 & 116.9 \\
& 25.2 & 198.5 & 37.7 & 160.0 \\
& $\mathrm{Z}_{1}$ & $\mathrm{Z}_{2}$ & $\mathrm{Z}_{1}$ & $\mathrm{Z}_{2}$ \\
\hline
\end{tabular}

$\mathrm{PCU}=$ Polymer coated area; PC_NPK $=$ Polymer coated N, P and K.

Unlike the past methods of prediction of nutrient release from CRF products, the method described in this study is rapid, reproducible, and requires no chemicals for extractions. This method also integrates the properties of coating material in determining the nutrient release at ambient temperature in the soil. No tedious extraction and analytical technique are required, except analysis of total $\mathrm{N}$ in the water. Therefore, the proposed method can be readily adapted by the fertilizer manufacturer or distributors for accurate labelling of the CRF release rate and duration.

\section{Conclusions}

This study demonstrated that $100^{\circ} \mathrm{C}$ nutrient release test in water was useful for prediction of nutrient release rate and duration at $25^{\circ} \mathrm{C}$. Therefore, a quick test done at 7 to $10 \mathrm{~d}$ is useful to predict the CRF release characteristics at $25^{\circ} \mathrm{C}$.

\section{REFERENCES}

[1] A. M. Dave and M. H. Mehta, "A Review on Controlled Release of Nitrogen Fertilizers through Polymeric Membrane Devices," Polymer Plastics Technology and Engineering, Vol. 38, No. 4, 1999, pp. 675-711. doi: $10.1080 / 03602559909351607$

[2] A. Shaviv, "Advances in Controlled Release Fertilizer," Advanced Agronomy, Vol. 71, 2000, pp. 1-49.

[3] A. J. Patel and G. C. Sharma, "Nitrogen Release Characteristics of Controlled Release Fertilizers during a Four month Soil Incubation," American Society of Horticultural Science, Vol. 102, 1977, pp. 364-367.

[4] T. K. Broschat and K. K. Moore, "Release Rates of Ammonium-Nitrogen, Nitrate-Nitrogen, Phosphorus, Potassium, Magnesium, Iron, and Manganese from Seven Controlled Release Fertilizers," Communications in Soil Science, Vol. 38, 2007, pp. 843-850. doi:10.1080/00103620701260946

[5] G. W. Sinclair and N. A. Peppas, "Analysis of Nonfickian Transport in Polymers Using Simplified Exponential Expressions," Journal of Membrane Science, Vol. 17, No. 3, 1984, pp. 329-332. doi:10.1016/S0376-7388(00)83223-8

[6] S. M. Al-Zahrani, "Controlled-Release of Fertilizers: Modeling and Simulation," International Journal of Engineering Science, Vol. 37, No. 10, 1998, pp. 1299-1307. doi:10.1016/S0020-7225(98)00120-7

[7] J. B. Schwartz, A. P. Simonelli, and W. I. Higuchi, "Drug Release from Wax Matrices: I. Analysis of Data with 
First-Order Kinetics and with the Diffusion Controlled Model," Journal of Pharmaceutical Science, Vol. 57, No. 2, 1996, pp. 274-278. doi:10.1002/jps.2600570206

[8] A. Shaviv, "Plant Response and Environment Aspects as Affected by Rate and Pattern of Nitrogen Release from Controlled Release N Fertilizers," The Netherlands, Kluwer Academy, 1996.

[9] A. Shaviv, S. Raban and E. Zaidel, "Modeling Controlled Nutrient Release from a Population of Polymer Coated Fertilizers: Statistically Based Model for Diffusion Release," Environmental Science and Technology, Vol. 37, No. 10, 2003, pp. 2257-2261. doi:10.1021/es0205277

[10] C. Du, D. Tang, J. Zhou, H. Wang and A. Shaviv, "Prediction of Nitrate Release from Polymer-Coated Fertilizers Using an Artificial Neural Network Model," Bioprocesses and Biosystems, Vol. 99, No. 4, 2007, pp. 478-486. doi:10.1016/j.biosystemseng.2007.12.003

[11] D. P. Li, X. C. Xu and H. B. Wang, "Review on the Standards of Slow Controlled Release Fertilizer at Home and Abroad," Phosphate Compounds and Fertilizer, Vol. 20, 2005, pp. 41-42.

[12] B. Q. Zhao, et al., "Research on Development Strategies of Fertilizer in China," Plant Nutrition and Fertilizer Science, Vol. 10, 2004, pp. 536-545.

[13] S. E. Allen, L. M. Hunt and G. Terman, "Nitrogen Release from Sulfur-Coated Urea as Affected by Coating Weight, Placement, and Temperature," Agronomy Journal, Vol. 63, No. 4, 1971, pp. 529-533. doi:10.2134/agronj1971.00021962006300040004x
[14] J. J. Oertli and O. R. Lunt, "Controlled Release of Fertilizer Materials by Incaspulating Membranes, I. Factors Influencing the Rate of Release," Soil Science Society of America Proceedings, Vol. 26, No. 6, 1962, pp. 579-583. doi:10.2136/sssaj1962.03615995002600060019x

[15] J. H. Chen, Y. P. Cao, H. Xu, Z. G. Fang and D. R. Mao, "Appraisal of Nitrogen Releasing Characteristics of Organic Polymer Coating Controlled Release Fertilizer," Plant Nutrition and Fertilizer, Vol. 8, 2002, pp. 44-47.

[16] M. Zhang, Y. C. Yang, F. P. Song and Y. X. Shi, "Study and Industrialized Development of Coated Controlled Release Fertilizers," Journal of Chemical Fertilizer Industry, Vol. 32, 2005, pp. 7-12.

[17] L. C. Medina, J. B. Sartain and T. A. Obreza, "Estimation of Release Properties of Slow-Release Fertilizer Material," Horticulture Technology, Vol. 19, pp. 13-15, 2009.

[18] J. J. Dai and X. L. Fan, "Study on the Rapid Method to Predict Longevity of Controlled Release Fertilizer Coated by Water Soluble Resin," Agricultural Science in China, Vol. 7, No. 9, 2008, pp. 1127-1132. doi:10.1016/S1671-2927(08)60155-8

[19] J. J. Dai, X. L. Fan, Y. L. Liang and L. X. Sun, "Study on Calibration of Standard Regression Curve of Fertilizer Solution Concentration by Conductivity Level," Phosphate Compound Fertilizers, Vol. 20, 2005, pp. 15-17.

[20] J. J. Dai, X. L. Fan, J. G. Yu and F. L. Wu, "The Method of Quickly Predicting Longevity of Controlled Release Fertilizer Coated with Thermoset Resin," Plant Nutrition and Fertilizer Science, Vol. 12, 2006, pp. 431-436. 